\title{
LA FALLA EN LA OVULACIÓN COMO UN COMPONENTE DE LA PATOGENIA DE LA ENFERMEDAD QUÍSTICA OVÁRICA BOVINA: ROL DE CITOQUINAS
}

\author{
Baravalle, M. E. ${ }^{1} ;$ Stassi, A. ${ }^{1} ;$ Velazquez, M. M. L.'; \\ Belotti, M. ${ }^{1}$; Ortega, H. H. ${ }^{1}$ \& Salvetti, N. R. ${ }^{1}$
}

\begin{abstract}
RESUMEN
La ovulación es considerada actualmente como un proceso inflamatorio agudo y a nivel local, las citoquinas cumplen papeles fundamentales debido a que influyen sobre la producción de diversos mediadores. Considerando los múltiples factores que intervienen en estos procesos (ovulación/inflamación), la alteración de uno o más componentes podría contribuir a la patogenia de enfermedades reproductivas como la enfermedad quística ovárica (COD), uno de los desórdenes reproductivos más frecuentes en el ganado bovino lechero. Esta enfermedad provoca cuantiosas pérdidas económicas para la producción pecuaria. En esta revisión, se actualizan conceptos asociados a la interacción entre el sistema inmune y los mecanismos fisiológicos responsables de la ovulación en el bovino.

Palabras claves: Ovarios, bovinos, enfermedad quística ovárica, citoquinas.
\end{abstract}

\section{SUMMARY}

Ovulation is currently considered an acute and local inflammatory process, and cytokines have fundamentals roles because they influence the production of several mediators. Considering the multiple factors involved in these processes (ovulation / inflammation), the alteration of one or more components may contribute to the pathogenesis of reproductive diseases as cystic ovarian disease (COD), one of the most common reproductive disorders in dairy cattle. This disease causes considerable economic losses for livestock. In this review, we updated concepts associated with the interaction between the immune system and the physiological mechanisms responsible of ovulation in cattle.

Key words: Ovary, bovine, cystic ovarian disease, cytokines.

1.- Facultad de Ciencias Veterinarias (UNL). Kreder 2805. (3080) Esperanza, provincia de Santa Fe. Manuscrito recibido el 19 de septiembre de 2013 y aceptado para su publicación el 11 de abril de 2014. 